\title{
Chryseobacterium flavum sp. nov., isolated from polluted soil
}

\author{
Yu Zhou, ${ }^{1} \dagger$ Jing Dong, ${ }^{1} \dagger$ Xu Wang, ${ }^{1}$ Xing Huang, ${ }^{1}$ Ke-Yun Zhang, ${ }^{1}$ \\ Yu-Oin Zhang, ${ }^{2,3}$ Yu-Feng Guo, ${ }^{4}$ Ren Lai ${ }^{1,5}$ and Wen-Jun Li ${ }^{2}$
}

Correspondence

Ren Lai

rlai72@njau.edu.cn

Wen-Jun Li

wjli@ynu.edu.cn

\begin{abstract}
${ }^{1}$ Key Laboratory of Microbiological Engineering of Agricultural Environment, Ministry of Agriculture, Life Sciences College of Nanjing Agricultural University, Nanjing, Jiangsu 210095, China

${ }^{2}$ Laboratory for Conservation and Utilization of Bio-Resources, Yunnan Institute of Microbiology and Yunnan University, Kunming, Yunnan 650091, China

${ }^{3}$ Institute of Medicinal Biotechnology, Chinese Academy of Medical Sciences and Peking Union Medical College, Beijing 100050, China

${ }^{4}$ Department of Environmental Science and Engineering, Tsinghua University, Beijing 100084, China

${ }^{5}$ Biotoxin Department of Key Laboratory of Animal Models and Human Disease Mechanisms, Kunming Institute of Zoology, Chinese Academy of Sciences, Kunming, Yunnan 650223, China
\end{abstract}

\begin{abstract}
A Gram-negative, non-motile, rod-shaped bacterial strain, designated CW-E $2^{\top}$, was isolated from a polluted soil sample collected from Jiangsu Province, China. A taxonomic study of the isolate, including phylogenetic analysis based on 16S rRNA gene sequences and phenotypic characteristics, was carried out. The predominant menaquinone was MK-6 and the major fatty acids were $\mathrm{i}-\mathrm{C}_{15: 0}, \mathrm{i}-\mathrm{C}_{17: 0} 3-\mathrm{OH}, \mathrm{i}-\mathrm{C}_{17: 1} \omega 9 \mathrm{c}$ and summed feature 4 . The $\mathrm{G}+\mathrm{C}$ content of the DNA was 37.2 mol\%. Based on phenotypic and genotypic characteristics, strain CW-E $2^{\top}$ represents a novel species of the genus Chryseobacterium for which the name Chryseobacterium flavum sp. nov. is proposed. The type strain is CW-E $2^{\top}\left(=\right.$ KCTC $12877^{\top}=$ CCTCC AB $\left.206147^{\top}\right)$.
\end{abstract}

The family Flavobacteriaceae represents the main bacterial lineage in the phylum Bacteroidetes (formerly the Cytophaga-Flexibacter-Bacteroides group) (Bernardet et al., 1996, 2002). Among the genera currently included in the family, Chryseobacterium, Bergeyella, Ornithobacterium, Empedobacter, Weeksella, Wautersiella, Elizabethkingia, Sejongia and Kaistella form a separate branch in phylogenetic trees (Vandamme et al., 1994; Kim et al., 2004, 2005b; Bernardet et al., 2002, 2006). At the time of writing, the genus Chryseobacterium contains 18 species with validly published names (Shimomura et al., 2005; Kim et al., 2005a; Young et al., 2005; de Beer et al., 2005, 2006; Bernardet et al., 2006; Quan et al., 2007). Members of the genus Chryseobacterium are strictly aerobic, non-motile, Gram-negative rods that produce flexirubin-type pigments and have a DNA G+C content of about 29-39 mol\%. Members of the genus Chryseobacterium occur in a variety of environments, including soil, fresh- and seawater, raw milk and chicken, diseased fish, bioreactor sludge and

†These authors contributed equally to this work.

Abbreviation: TEM, transmission electron microscopy.

The GenBank/EMBL/DDBJ accession number for the 16S rRNA gene sequence of strain CW-E $2^{\top}$ is EF154516. clinical samples (Yamaguchi \& Yokoe, 2000; Hugo et al., 2003; Kim et al., 2005a; de Beer et al., 2005, 2006; Bernardet et al., 2006; Quan et al., 2007). In the course of an investigation of the bacterial community in a soil sample contaminated by atrazine, ethametsulfuron, glyphosate and other herbicides from a chemical factory in the suburb of Nanjing City, Jiangsu Province, China, one bacterial strain, CW-E $2^{\mathrm{T}}$, which had the ability to decompose atrazine (data not shown), was isolated and subjected to a polyphasic taxonomy study. It is proposed that this strain represents a novel species in the genus Chryseobacterium, Chryseobacterium flavum sp. nov.

Strain CW-E $2^{\mathrm{T}}$ was isolated by plating dilutions of a soil sample on LB agar (Sambrook \& Russell, 2002) incubated at $30{ }^{\circ} \mathrm{C}$ for 3 days. The strain was preserved in a $20 \%$ $(\mathrm{v} / \mathrm{v})$ glycerol solution in distilled water at $-80{ }^{\circ} \mathrm{C}$. Biomass for molecular systematic and chemotaxonomic studies was obtained from LB broth ( $\mathrm{pH}$ adjusted to 7.0) cultures incubated at $30{ }^{\circ} \mathrm{C}$ for 2 days in shake flasks (about 180 r.p.m.).

Cellular morphology of the isolate was observed by transmission electron microscopy (TEM) (model H-7650; Hitachi) examination of bacterial cells grown for $18 \mathrm{~h}$ on LB agar and 


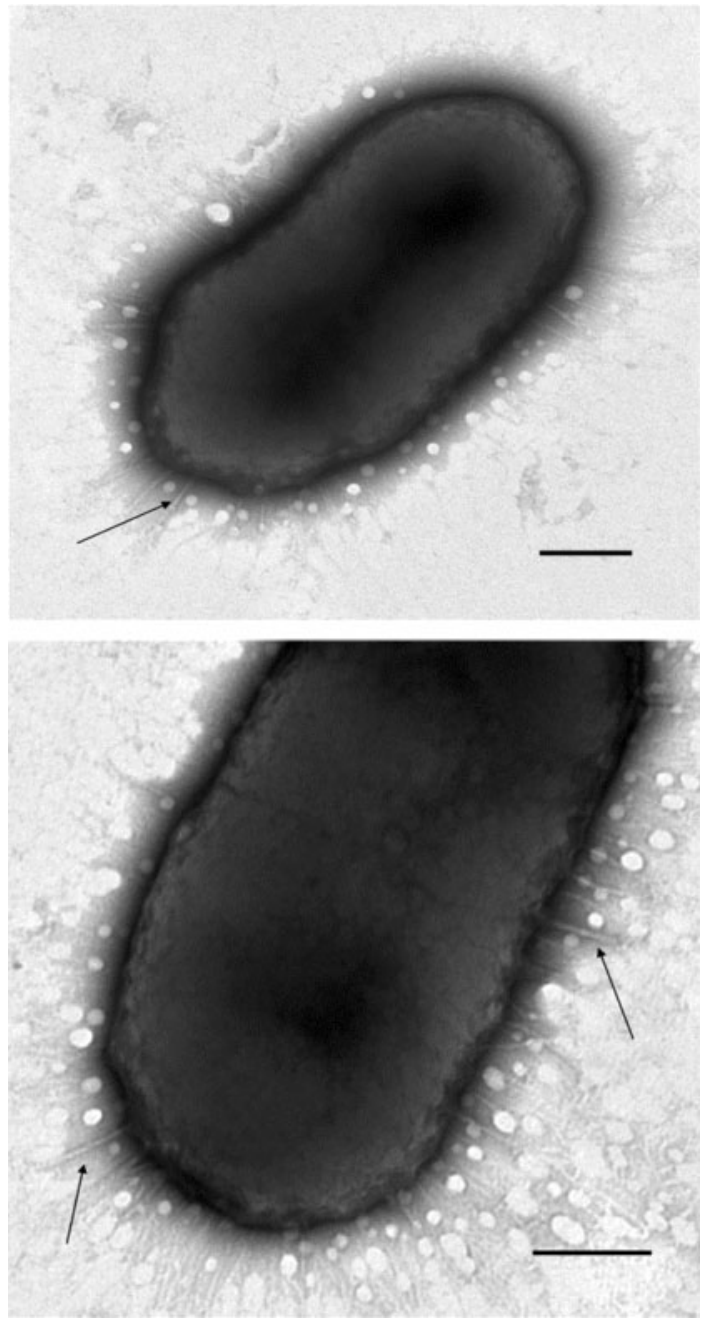

Fig. 1. TEMs of cells of strain CW-E $2^{\top}$ grown on LB agar for $18 \mathrm{~h}$ at $30^{\circ} \mathrm{C}$. Arrows indicate fimbriae. Bars, $200 \mathrm{~nm}$.

prepared as described by Nedashkovskaya et al. (2005) (Fig. 1). Acid production from carbohydrates was investigated using the media and methods described by Yamaguchi \& Yokoe (2000). Utilization of various carbon sources was investigated by using modified ammonia salt-sugar medium $[0.2 \%$ $\left(\mathrm{NH}_{4}\right)_{2} \mathrm{SO}_{4}, 0.05 \% \mathrm{NaH}_{2} \mathrm{PO}_{4} \cdot \mathrm{H}_{2} \mathrm{O}, 0.02 \% \mathrm{MgSO}_{4} \cdot 7 \mathrm{H}_{2} \mathrm{O}$, $0.01 \% \mathrm{CaCl}_{2} \cdot 2 \mathrm{H}_{2} \mathrm{O}$ and $\left.0.05 \% \mathrm{~K}_{2} \mathrm{HPO}_{4}\right]$ containing $1 \%$ of each tested carbon source. Growth was tested at 0,5 , $10,25,30,35,37,40,42,45$ and $50{ }^{\circ} \mathrm{C}$ on $\mathrm{LB}$ agar. $\mathrm{NaCl}$ and $\mathrm{pH}$ tolerance were tested using $\mathrm{LB}$ broth adjusted to various $\mathrm{pH}$ values $(3.0,6.0,7.0,7.8,8.0,10.0,11.0$ and 12.0) and $\mathrm{NaCl}$ concentrations (1, 4, 7 and 10\%) (Zhou et al., 2007). Growth was tested on cetrimide agar, $\beta$ hydroxybutyrate agar, MacConkey agar and Simmons' citrate agar. Susceptibility to antibiotics was examined as described by Nedashkovskaya et al. (2003, 2005). Flexirubin-type pigments were identified using the $\mathrm{KOH}$ test as described by Bernardet et al. (2002). Gram-staining and other phenotypic characteristics were determined according to the methods of Gerhardt et al. (1994). Detailed morphological, physiological and biochemical characteristics of strain $\mathrm{CW}-\mathrm{E} 2^{\mathrm{T}}$ are given in Table 1 and the species description.

Menaquinones were extracted from lyophilized cells and determined according to $\mathrm{Hu}$ et al. (2001). The predominant menaquinone was MK-6. The fatty acids were extracted, methylated and analysed using the standard MIDI (Microbial Identification) system as described by Sasser (1990). The major fatty acids of strain CW-E $2^{\mathrm{T}}$ were $\mathrm{i}-\mathrm{C}_{15: 0}, \mathrm{i}-\mathrm{C}_{17: 0} 3-\mathrm{OH}, \mathrm{i}-\mathrm{C}_{17: 1} \omega 9 c$ and summed feature 4 (comprising $\mathrm{i}-\mathrm{C}_{15: 0} \quad 2-\mathrm{OH}$ and/or $\mathrm{C}_{16: 1} \omega 7 c$ and/or $\left.\mathrm{C}_{16: 1} \omega 7 t\right)$. Detailed fatty acid profiles of strain CW-E $2^{\mathrm{T}}$ and its closest relatives are given in Table 2.

Genomic DNA of strain CW-E $2^{\mathrm{T}}$ was prepared following the method of Marmur (1961) and the DNA G + C content was determined using the thermal denaturation method (Mandel \& Marmur, 1968). The DNA G+C content of strain $\mathrm{CW}-\mathrm{E} 2^{\mathrm{T}}$ was $37.2 \mathrm{~mol} \%$.

Table 1. Phenotypic characteristics that differentiate Chryseobacterium flavum $\mathrm{CW}-\mathrm{E} 2^{\top}$ from its closest relatives

Species: 1, C. flavum $(n=1) ; 2$, C. joostei $(n=11) ; 3$, C. gleum $(n=5)$; $4, C$. indologenes $(n=45) ; 5, C$. shigense $(n=1) ; 6, C$. vrystaatense $(n=36) .+$, Positive; - , negative; $\mathrm{v}$, variable; D, delayed; NA, no data available; PS, polluted soil; RM, raw milk; RC, raw chicken; CS, clinical samples; LAB, lactic acid beverage. For all species, indole production was positive. Data from Hugo et al. (2003), Shimomura et al. (2005) and de Beer et al. (2005).

\begin{tabular}{|lcccccc|}
\hline Characteristic & $\mathbf{1}$ & $\mathbf{2}$ & $\mathbf{3}$ & $\mathbf{4}$ & $\mathbf{5}$ & $\mathbf{6}$ \\
\hline Habitat & PS & RM & CS & CS & LAB & RC \\
Growth on/at: & & & & & & \\
$\quad$ MacConkey agar & + & + & + & + & - & - \\
$5{ }^{\circ} \mathrm{C}$ & + & + & - & - & + & + \\
$37{ }^{\circ} \mathrm{C}$ & + & - & + & + & - & - \\
$42{ }^{\circ} \mathrm{C}$ & + & - & - & - & - & - \\
Growth on nutrient agar sup- & + & NA & NA & NA & NA & - \\
plemented with 5\% NaCl & & & & & & \\
Enzyme activities: & & & & & & \\
DNase & - & + & + & + & NA & + \\
Urease & - & $\mathrm{V}$ & + & - & - & + \\
$\beta$-Galactosidase & + & - & - & - & NA & NA \\
Nitrate reduction & - & - & + & - & - & - \\
Nitrite reduction & - & - & + & - & NA & + \\
Hydrolysis of: & & & & & & \\
Tyrosine & + & + & + & - & NA & - \\
Tween 80 & + & + & + & + & NA & + \\
Starch & + & + & + & + & + & - \\
Acid production from: & & & & & & \\
D-Fructose & + & + & + & D & + & NA \\
D-Mannitol & - & $\mathrm{V}$ & - & - & - & NA \\
D-Xylose & + & - & + & - & - & NA \\
Mean DNA G $+\mathrm{C}$ content & 37.2 & 36.8 & 38 & 38.5 & 36.6 & 37.1 \\
(mol\%) & & & & & & \\
\hline
\end{tabular}


Table 2. Cellular fatty acid content (\%) of Chryseobacterium flavum CW-E $2^{\top}$ and its closest relatives

Species: 1, C. flavum ( $n=1) ; 2$, C. joostei $(n=11) ; 3$, C. gleum $(n=5) ; 4$, C. indologenes $(n=45) ; 5$, C. shigense $(n=1) ; 6$, C. vrystaatense $(n=36)$. Some of the Chryseobacterium species included in this table were cultivated under different conditions. Means \pm SD are given where more than one strain was tested. ND, Not detected; TR, trace (fatty acids amounting to less than 1\%). Data from Hugo et al. (2003), Shimomura et al. (2005) and de Beer et al. (2005).

\begin{tabular}{|c|c|c|c|c|c|c|}
\hline Fatty acid & 1 & 2 & 3 & 4 & 5 & 6 \\
\hline $\mathrm{i}-\mathrm{C}_{15: 0}$ & 35.1 & $34.6 \pm 2.0$ & $35.4 \pm 2.9$ & $34.3 \pm 4.9$ & 39.7 & $41.8 \pm 1.4$ \\
\hline $\mathrm{i}-\mathrm{C}_{15: 0} 3-\mathrm{OH}$ & 3.7 & $2.9 \pm 0.3$ & $2.5 \pm 0.1$ & $2.6 \pm 0.2$ & 4.1 & $2.7 \pm 0.3$ \\
\hline $\mathrm{C}_{16: 0} 3-\mathrm{OH}$ & 2.0 & $1.2 \pm 0.2$ & $1.1 \pm 0.1$ & $1.0 \pm 0.2$ & 1.3 & $1.3 \pm 0.3$ \\
\hline $\mathrm{i}-\mathrm{C}_{17: 0}$ & TR & TR & $1.6 \pm 0.6$ & TR & TR & TR \\
\hline $\mathrm{i}-\mathrm{C}_{17: 0} 3-\mathrm{OH}$ & 18.5 & $20.1 \pm 1.2$ & $21.8 \pm 0.3$ & $19.2 \pm 1.8$ & 19.6 & $15.4 \pm 1.8$ \\
\hline Unknown $13.566^{*}$ & 1.9 & $1.1 \pm 0.2$ & $1.2 \pm 0.4$ & $2.1 \pm 0.7$ & 2.4 & $1.4 \pm 0.3$ \\
\hline Unknown $16.580^{\star}$ & 1.5 & $1.6 \pm 0.1$ & $1.7 \pm 0.1$ & $1.7 \pm 0.2$ & 1.0 & $1.2 \pm 0.2$ \\
\hline Summed feature $4 \dagger$ & 13.3 & $12.1 \pm 1.3$ & $11.8 \pm 0.8$ & $11.1 \pm 1.3$ & 12.4 & $9.1 \pm 2.3$ \\
\hline
\end{tabular}

${ }^{\star}$ Numbers indicate the equivalent chain-length.

$\dagger$ Fatty acids that could not be separated by GC using the Microbial Identification System (Microbial ID) software were considered summed features. Summed feature 4 contains i- $\mathrm{C}_{15: 0} 2-\mathrm{OH}$ and/or $\mathrm{C}_{16: 1} \omega 7 \mathrm{c}$ and/or $\mathrm{C}_{16: 1} \omega 7 t$.

PCR amplification of the 16S rRNA gene was performed as described by $\mathrm{Xu}$ et al. (2003). Phylogenetic analysis was performed using the software packages PHYLIP (Felsenstein, 1993) and MEGA version 3.1 (Kumar et al., 2001) after multiple alignment of data by CLUSTAL_X (Thompson et al., 1997). Distances (distance options according to the Kimura twoparameter model; Kimura, 1980, 1983) and clustering were based on the neighbour-joining (Saitou \& Nei, 1987) and maximum-likelihood (Felsenstein, 1981) methods. Bootstrap analysis (1000 resamplings) was used to evaluate the topology of the neighbour-joining tree (Felsenstein, 1985).

The almost complete 16S rRNA gene sequence (1440 bp in length) of strain CW-E $2^{\mathrm{T}}$ and reference sequences selected from GenBank following BLAST searches were used to draw the phylogenetic tree. Phylogenetic analyses showed that strain CW-E $2^{\mathrm{T}}$ belongs to the genus Chryseobacterium but shares only $94.9,93.9$ and $93.9 \% 16 \mathrm{~S}$ rRNA gene sequence similarity with its closest relatives Chryseobacterium joostei LMG $18212^{\mathrm{T}}$, Chryseobacterium gleum ATCC $35910^{\mathrm{T}}$ and Chryseobacterium indologenes ATCC $29897^{\mathrm{T}}$, respectively (Fig. 2).

Differential phenotypic characteristics (Table 1) could be used to distinguish the isolate from other Chryseobacterium species. Hence, strain CW-E $2^{\mathrm{T}}$ represents a novel species for which the name Chryseobacterium flavum sp. nov. is proposed.

\section{Description of Chryseobacterium flavum sp. nov.}

Chryseobacterium flavum (fla'vum. L. neut. adj. flavum yellow, the colour of colonies or pigment).

Cells are Gram-negative, non-motile, non-spore-forming, aerobic and chemo-organotrophic rods $(0.5-0.7 \times 1.1-$
$1.3 \mu \mathrm{m})$ that are covered by fimbriae. Colonies on LB agar plates are circular, convex, shiny, bright-yellow-coloured and smooth, $1.0-1.5 \mathrm{~mm}$ in diameter, with a ropy consistency. Growth occurs on trypticase soy agar, cetrimide agar, MacConkey agar and $\beta$-hydroxybutyrate ( $\beta$-hydroxybutyrate inclusions are not produced). No growth occurs on Simmons' citrate agar. Growth occurs at $5-42{ }^{\circ} \mathrm{C}$, pH $5.0-9.0$ and with $0-6 \% \mathrm{NaCl}$ (optimum growth at $30-35{ }^{\circ} \mathrm{C}, \mathrm{pH} 6.0-7.0$ and $1 \% \mathrm{NaCl}$ ). Nondiffusible flexirubin-type yellow pigments are produced. Casein, gelatin, starch and Tween 20 are hydrolysed. DNA, cellulose and chitin are not hydrolysed. Acid is produced from D-fructose, maltose, trehalose and D-xylose; but not from adonitol, D-arabinose, cellobiose, dulcitol, L-fucose, D-galactose, D-glucose, inositol, D-lactose, D-mannitol, Dmelezitose, D-melibiose, L-raffinose, L-rhamnose, D-sorbitol, L-sorbose or sucrose. Adonitol, aesculin, D-arabinose, cellobiose, dextrin, D-fructose, D-galactose, glucosamine, D-glucose, inositol, inulin, D-lactose, maltose, D-mannose, D-melezitose, D-melibiose, D-ribose, D-sorbitol, sucrose, trehalose, turanose, xylitol and D-xylose are utilized. Citrate, acetate, adonitol, dulcitol, D-erythrose, malonate, D-mannitol, melezitose, D-raffinose, tartrate, salicin and Dsorbitose are not utilized. Oxidase, catalase, $\beta$-galactosidase, phenylalanine decarboxylase, arginine dihydrolase and lipase activities are present. Methyl $\alpha$-D-glucosidase, ornithine decarboxylase, lysine decarboxylase, arginine decarboxylase, urease and DNase activities are absent. Nitrate and nitrite are not reduced. $\mathrm{H}_{2} \mathrm{~S}$ (triple-sugar iron test) is not produced. Methyl red and Voges-Proskauer tests are negative. Indole is produced. KCN $(0.0075 \%)$ is not tolerated. Susceptible to carbenicillin, tetracycline, doxycycline, gentamicin, penicillin G, kanamycin, vancomycin, erythromycin, rifampicin, neomycin, streptomycin 


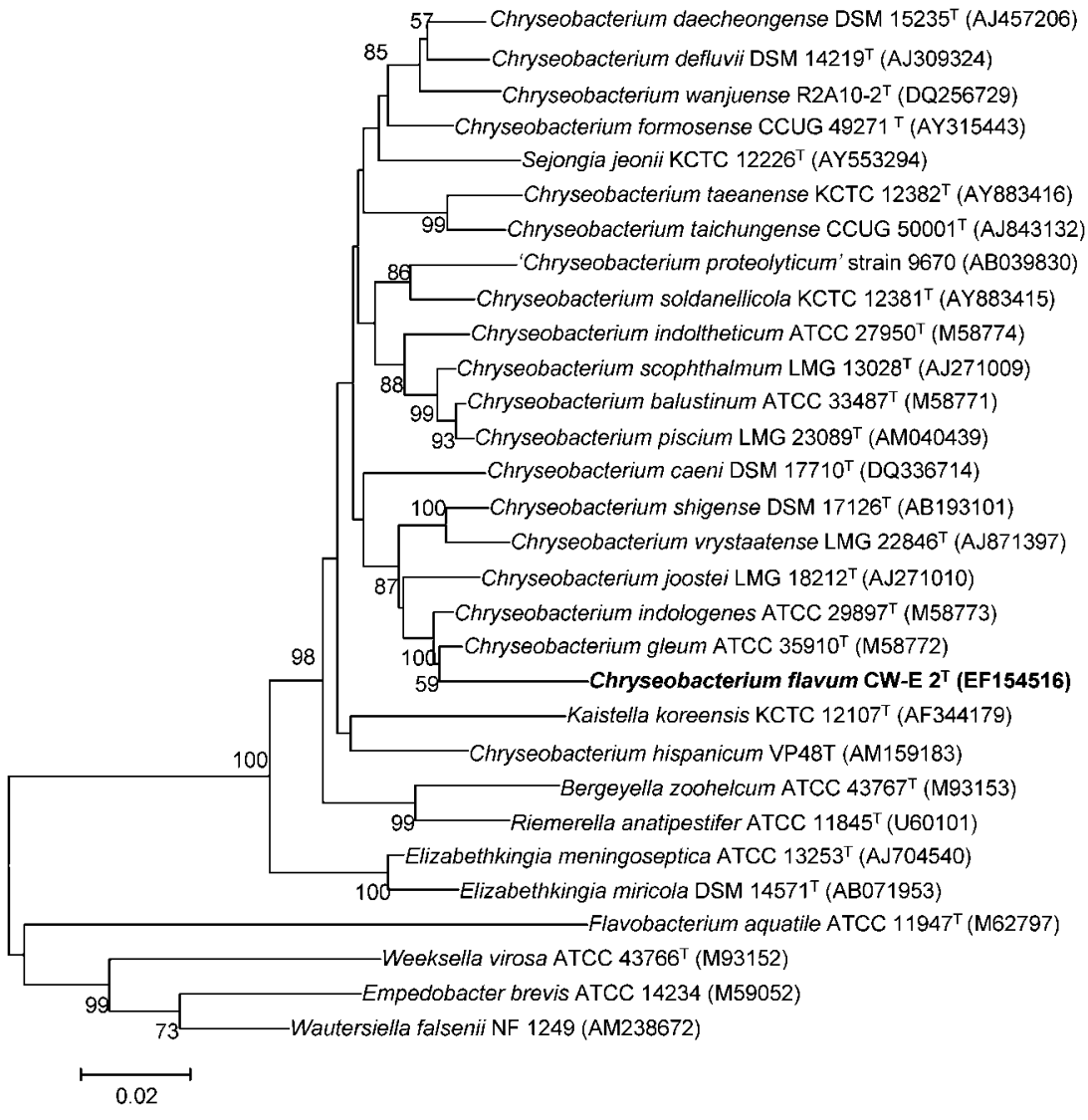

Fig. 2. Neighbour-joining phylogenetic tree based on 16S rRNA gene sequences of strain CW-E $2^{\top}$, other members of the genus Chryseobacterium, and representatives of the family Flavobacteriaceae. Numbers at nodes indicate bootstrap values (\%) greater than $50 \%$. Bar, 0.02 substitutions per nucleotide position. The maximum-likelihood tree showed essentially the same topology (data not shown). and chloramphenicol; resistant to ampicillin, lincomycin and polymixin $\mathrm{B}$. The predominant menaquinone is MK-6. The major fatty acids are $\mathrm{i}-\mathrm{C}_{15: 0}(35.1 \%), \mathrm{i}-\mathrm{C}_{17: 0} 3-\mathrm{OH}$ $(18.5 \%)$, i-C $17: 1 \omega 9 c(16.8 \%)$ and summed feature 4 (13.3\%, comprising i- $\mathrm{C}_{15: 0} 2-\mathrm{OH}$ and/or $\mathrm{C}_{16: 1} \omega 7 c$ and/or $\left.\mathrm{C}_{16: 1} \omega 7 t\right)$. The DNA G + C content is $37.2 \mathrm{~mol} \%$.

The type strain is CW-E $2^{\mathrm{T}}\left(=\mathrm{KCTC} 12877^{\mathrm{T}}=\mathrm{CCTCC} \mathrm{AB}\right.$ $206147^{\mathrm{T}}$ ), isolated from the surface layer of polluted soil from Nanjing, Jiangsu Province, China.

\section{Acknowledgements}

The authors are grateful to the editor and two anonymous reviewers for helpful comments. This work was supported by grants from the National Natural Science Foundation of China (Project no. 30600001), the Jiangsu Natural Science Foundation (BK2005422) and the Yunnan Science and Technology Commission (2005C0054M). W.-J.L. was also supported by the Program for New Century Excellent Talent in University (NCET).

\section{References}

Bernardet, J.-F., Segers, P., Vancanneyt, M., Berthe, F., Kersters, K. \& Vandamme, P. (1996). Cutting a Gordian knot: emended classification and description of the genus Flavobacterium, emended description of the family Flavobacteriaceae, and proposal of
Flavobacterium hydatis nom. nov. (basonym, Cytophaga aquatilis Strohl and Tait 1978). Int J Syst Bacteriol 46, 128-148.

Bernardet, J.-F., Nakagawa, Y. \& Holmes, B. (2002). Proposed minimal standards for describing new taxa of the family Flavobacteriaceae and emended description of the family. Int J Syst Evol Microbiol 52, 1049-1070.

Bernardet, J.-F., Hugo, C. \& Bruun, B. (2006). The genera Chryseobacterium and Elizabethkingia. In The Prokaryotes: Handbook on the Biology of Bacteria, 3rd edn, vol. 7, pp. 638-676. Edited by M. Dworkin, S. Falkow, E. Rosenberg, K.-H. Schleifer \& E. Stackebrandt. New York: Springer-Verlag.

de Beer, H., Hugo, C.-J., Jooste, P.-J., Willems, A., Vancanneyt, M., Coenye, T. \& Vandamme, P. (2005). Chryseobacterium vrystaatense sp. nov., isolated from raw chicken in a chicken-processing plant. Int $J$ Syst Evol Microbiol 55, 2149-2153.

de Beer, H., Hugo, C.-J., Jooste, P.-J., Vancanneyt, M., Coenye, T. \& Vandamme, P. (2006). Chryseobacterium piscium sp. nov., isolated from fish of the South Atlantic Ocean off South Africa. Int J Syst Evol Microbiol 56, 1317-1322.

Felsenstein, J. (1981). Evolutionary trees from DNA sequences: a maximum likelihood approach. J Mol Evol 17, 368-376.

Felsenstein, J. (1985). Confidence limits on phylogenies: an approach using the bootstrap. Evolution 39, 783-791.

Felsenstein, J. (1993). PHYLIP (phylogeny inference package), version 3.5c. Distributed by the author. Department of Genome Sciences, University of Washington, Seattle, USA.

Gerhardt, P., Murray, R. G. E., Wood, W. A. \& Krieg, N. R. (editors) (1994). Methods for General and Molecular Bacteriology. Washington, DC: American Society for Microbiology. 
Hu, H.-Y., Lim, B.-R., Naohiro, G. \& Koich, F.-J. (2001). Analytical precision and repeatability of respiratory quinones for quantitative study of microbial community structure in environmental samples. $J$ Microbiol Methods 47, 17-24.

Hugo, C.-J., Segers, P., Hoste, B., Vancanneyt, M. \& Kersters, K. (2003). Chryseobacterium joostei sp. nov., isolated from the dairy environment. Int J Syst Evol Microbiol 53, 771-777.

Kim, M. K., Im, W. T., Shin, Y. K., Lim, J. H., Kim, S. H., Lee, B. C., Park, M. Y., Lee, K. Y. \& Lee, S. T. (2004). Kaistella koreensis gen. nov., sp. nov., a novel member of the Chryseobacterium-Bergeyella-Riemerella branch. Int J Syst Evol Microbiol 54, 2319-2324.

Kim, K. K., Bae, H.-S., Schumann, P. \& Lee, S. T. (2005a). Chryseobacterium daecheongense sp. nov., isolated from freshwater lake sediment. Int J Syst Evol Microbiol 55, 133-138.

Kim, K. K., Kim, M. K., Lim, J. H., Park, H. Y. \& Lee, S. T. (2005b). Transfer of Chryseobacterium meningosepticum and Chryseobacterium miricola to Elizabethkingia gen. nov. as Elizabethkingia meningoseptica comb. nov. and Elizabethkingia miricola comb. nov. Int J Syst Evol Microbiol 55, 1287-1293.

Kimura, M. (1980). A simple method for estimating evolutionary rates of base substitutions through comparative studies of nucleotide sequence. J Mol Evol 16, 111-120.

Kimura, M. (1983). The Neutral Theory of Molecular Evolution. Cambridge: Cambridge University Press.

Kumar, S., Tamura, K., Jakobsen, I.-B. \& Nei, M. (2001). MEGA2: molecular evolutionary genetics analysis software. Bioinformatics 17, 1244-1245.

Mandel, M. \& Marmur, J. (1968). Use of ultraviolet absorbancetemperature profile for determining the guanine plus cytosine content of DNA. Methods Enzymol 12B, 195-206.

Marmur, J. (1961). A procedure for the isolation of deoxyribonucleic acid from microorganisms. J Mol Biol 3, 208-218.

Nedashkovskaya, O. I., Suzuki, M., Vysotskii, M. V. \& Mikhailov, V. V. (2003). Reichenbachia agariperforans gen. nov., sp. nov., a novel marine bacterium in the phylum Cytophaga-FlavobacteriumBacteroides. Int J Syst Evol Microbiol 53, 81-85.

Nedashkovskaya, O. I., Kim, S. B., Suzuki, M., Shevchenko, L. S., Lee, M. S., Lee, K. H., Park, M. S., Frolova, G. M., Oh, H. W. \& other authors (2005). Pontibacter actiniarum gen. nov., sp. nov., a novel member of the phylum 'Bacteroidetes', and proposal of Reichenbachiella gen. nov. as a replacement for the illegitimate prokaryotic generic name Reichenbachia Nedashkovskaya et al. 2003. Int J Syst Evol Microbiol 55, 2583-2588.

Quan, Z.-X., Kim, K. K., Kim, M. K., Jin, L. \& Lee, S. T. (2007). Chryseobacterium caeni sp. nov., isolated from bioreactor sludge. Int $J$ Syst Evol Microbiol 57, 141-145.

Saitou, N. \& Nei, M. (1987). The neighbor-joining method: a new method for reconstructing phylogenetic trees. Mol Biol Evol 4, $406-425$.

Sambrook, J. \& Russell, D. W. (2002). Molecular Cloning: a Laboratory Manual, pp. 1595-1596, 3rd edn. Cold Spring Harbor, NY: Cold Spring Harbor Laboratory.

Sasser, M. (1990). Identification of bacteria by gas chromatography of cellular fatty acids. USFCC Newsletter 20, 1-6.

Shimomura, K., Kaji, S. \& Hiraishi, A. (2005). Chryseobacterium shigense sp. nov., a yellow-pigmented, aerobic bacterium isolated from a lactic acid beverage. Int J Syst Evol Microbiol 55, 1903-1906.

Thompson, J. D., Gibson, T. J., Plewniak, F., Jeanmougin, F. \& Higgins, D. G. (1997). The CLUSTAL_X windows interface: flexible strategies for multiple sequence alignment aided by quality analysis tools. Nucleic Acids Res 25, 4876-4888.

Vandamme, P., Bernardet, J.-F., Segers, P., Kersters, K. \& Holmes, B. (1994). New perspectives in the classification of the flavobacteria: description of Chryseobacterium gen. nov., Bergeyella gen. nov., and Empedobacter nom. rev. Int J Syst Bacteriol 44, 827-831.

Xu, P., Li, W.-J., Xu, L.-H. \& Jiang, C.-L. (2003). A microwave-based method for genomic DNA extraction from Actinomycetes. Microbiology 30, 82-84 (in Chinese)

Yamaguchi, S. \& Yokoe, M. (2000). A novel protein-deamidating enzyme from Chryseobacterium proteolyticum sp. nov., a newly isolated bacterium from soil. Appl Environ Microbiol 66, 3337-3343.

Young, C.-C., Kämpfer, P., Shen, F.-T., Lai, W.-A. \& Arun, A. B. (2005). Chryseobacterium formosense sp. nov., isolated from the rhizosphere of Lactuca sativa L. (garden lettuce). Int J Syst Evol Microbiol 55, 423-426.

Zhou, Y., Wang, X., Liu, H., Zhang, K.-Y., Zhang, Y.-O., Lai, R. \& Li, W.-J. (2007). Pontibacter akesuensis sp. nov., isolated from a desert soil in China. Int J Syst Evol Microbiol 57, 321-325. 